\title{
Scoring Tradition, Making Nation: Zubir Said's Traditionalised Film Music for Dang Anom
}

\author{
Adil Johan \\ Institute of Ethnic Studies (KITA), \\ Universiti Kebangsaan Malaysia (UKM), \\ 43600 Bangi, Selangor, Malaysia \\ e-mail: adiljo@ukm.edu.my
}

\begin{abstract}
The Malay-language films produced by the Cathay-Keris Studio in 1950s to 1960s Singapore were known for their 'traditional' narratives based on Malay folklore and legends set in the pre-colonial Malay world. Made during a period of nation-making in the region, these films used musical accompaniment that had to be culturally-rooted in the music of the Malay Peninsula while expressing the region's aspirations for postcolonial independence. Interestingly, this task was undertaken prominently by the film composer, Zubir Said, who was not a citizen of Malay-majority Malaysia. Instead, he was commemorated as a national icon of Singapore, in which Malays form a minority. This paper aims to unravel the paradoxical process of 'traditionalising' national culture in a period of cosmopolitan postcoloniality in the Malay world. Through an intertextual study of his biography and film score analysed against the history of Malay nationalism, this article unravels the 'traditionalised' Malay musical aesthetic established through the musical compositions of Zubir Said in historically-themed Malay films. The article analyses the use of musical motifs and styles in Zubir Said's music for Hussein Hanniff's Dang Anom (1962). The juxtaposition of an aesthetically-traditional film score against the film's anti-feudal narrative results in a critique of archaic notions of tradition that articulates a subversive message of ethical modernity, freedom and self-determination. In conclusion, this intertextual analysis of film, music and history reveals how the melodic construction or scoring of musical tradition on the silver-screen was concomitant with the postcolonial aspirations and contradictions of nation-making in the Malay world.
\end{abstract}

Keywords: film music, Malay world, nationalism, postcolonial, Zubir Said

\section{Introduction}

In 1953, the release of the first Malay film to include original background music by a local composer marked a watershed in the musical history of the Malay Peninsula. ${ }^{1}$ That composer was the already prolific bangsawan musician, record producer, and film song composer, Zubir Said. Until then, films of the Singapore- 
based Malay film industry used pre-recorded European orchestral music to save on production costs (Rohana Zubir, 2012, pp. 82 \& 84, citing Zubir Said, 1984, Reel 13). Following his foray into scoring film music, Zubir Said won two awards, first from the 'Sixth Asian Film Festival' in the category of 'Best Film Portraying Traditions and Folk Music' for the film, Jula Juli Bintang Tiga (The Magical Tale of The Three Stars, 1959, Dir. B.N. Rao), and then from the ninth in the category 'Best Folk Songs and Dances' for the film Dang Anom (1962, Dir. Hussein Haniff). These Malay-language films produced by the Cathay-Keris Studio in 1950s to 1960s Singapore were known for their 'traditional' narratives based on Malay folklore and legends set in the pre-colonial Malay world. Made during a period of nation-making in the region, these films used musical accompaniment that had to be culturallyrooted in the music of the Malay Peninsula while expressing the region's aspirations for postcolonial independence. Interestingly, this task was undertaken prominently by the film composer, Zubir Said, who was not a citizen of Malay-majority Malaysia. Instead, he was commemorated as a national icon of Singapore, in which Malays form a minority. This was largely due to his penning of the Singaporean state's national anthem, 'Majulah Singapura (Onward Singapore)'.

In analysing Zubir Said's music in the film Dang Anom, this article aims to unravel the paradoxical process of traditionalising national culture in a period of cosmopolitan postcoloniality in the Malay world. Through an intertextual study of his biography and film score analysed against the history of Malay nationalism, this study will reveal how a 'traditionalised' Malay musical aesthetic was established through the musical compositions of Zubir Said in historically-themed Malay films. This musical aesthetic is discerned through an analysis of musical motifs and styles in Zubir Said's music for Hussein Hanniff's Dang Anom. The juxtaposition of an aesthetically-traditional film score against the film's anti-feudal narrative results in a critique of archaic notions of tradition that, upon deeper analysis, subversively articulates a message of ethical modernity, freedom and self-determination. An intertextual analysis of film, music and history aims to reveal how the making of musical tradition on the silver-screen was concomitant with the postcolonial aspirations and contradictions of nation-making in the Malay world.

\section{Constituting Nation in Film Music}

Zubir Said was a paragon of the fluid Malay cosmopolitan of the postwar years. Born of Minangkabau descent in Bukit Tinggi, Sumatra, he embarked on a professional music career in Singapore in 1928 and eventually became a citizen in 1967, two years after the formation of Singapore. Prior to composing for film, he worked as a photographer for the Indonesian Embassy and managed the Indonesian Club in Singapore (Rohana Zubir, 2012, p.74). After composing Singapore's national anthem, he was invited in 1957 to write a national anthem for the Federation of Malaya but all three of his submissions were rejected (pp. 106-107). Riding on the wave of emerging nationalism leading up to Malayan independence from British colonial rule, he passionately advocated for Malay nationalism in 
music by composing numerous patriotic songs and writing nationalistic articles (Rohana Zubir, 2012, pp. 102-120; Zubir Said, 1956/1957, 1967, 2012a, 2012b).

Zubir Said's film music was composed with the intention of articulating a cultural style that embodied a Malay musical aesthetic, but he did this in a postcolonial environment that influenced the need of cementing an authentic musical tradition. In effect, his music constituted an aesthetic of nationhood in Malay vernacular films. While drawing from local folk music practices, though, he also had to adapt such music to the formal methods and structures of western orchestration for film. ${ }^{2}$ His authorial agency thus imposed what could be included (or excluded) to represent a Malay 'mood' or sound in his selection of instrumentation, melodies and textures (Rohana Zubir, 2012, p.82). In unravelling the postcolonial structures of knowledge that governed Zubir Said's creativity I apply a methodology of intertextual musical analysis to consider the relationship of authorial agency and larger structures of power. The application of postcolonial analysis in studying music requires

meticulous attention to textual detail, but always sees such analysis as subsidiary to the larger project of thinking through the implications of cultural expression for understanding asymmetrical power relations and concomitant processes of marginalization and denigration. (Born \& Hesmondhalgh, 2000, p.5)

However, to what extent are internal process of 'marginalisation' and 'denigration' present in Zubir Said's music? For this study, instances of exclusion are more appropriately observed in the traditionalised Malay aesthetic of Zubir Said's compositions. His film composition and arrangement methods involved processes of exclusion that ultimately left out certain local musical practices and traditional instruments in favour of modern instrumentation as this was what he deemed aesthetically acceptable and practical for the modern medium of film. For example, the vibraphone, used extensively in his film music, approximated the sound of the regionally-pervasive gamelan. A gamelan's tuning does not adhere to western conventions but, the diatonic tuning of the vibraphone was seamlessly incorporated with other western instruments used such as pianos, saxophones, guitars and violins. These western instruments would then be used to reproduce Malay-sounding melodies derived from local genres such as asli and dondang sayang, albeit within a diatonic musical arrangement or score facilitated by western notation. Thus, Zubir Said was also exoticising, to an extent, the musical cultures of the Malay Peninsula and subsuming them under aesthetic boundaries of what he considered 'traditional' Malay music. This is not as explicitly problematic as nonwestern music portrayed in films from the west resulting in the 'assumed vernacular' film music (Slobin 2008a, pp. 25-29). The apparent auto-exoticism heard in Zubir Said's film music can, instead, be considered a 'constitutive vernacular', as the postcolonial power relations that are present in western films musically representing the non-west were not an issue in Malay films. In the case of Zubir Said's film music, the musical vernacular was not 'assumed' from a detached positionality, but rather created from the composer's local cultural and political 
position in constructing a sound for a Malay nation-in-the-making through Malay film music.

More so, Zubir Said's film music articulates the desire of Malay nationalists during the mid-1950s to early 1960 s to actively create a modern national culture that was independent of colonial rule, but, ironically, not free of colonial-western criteria of nationhood. Thus, while Zubir Said was, retrospectively, reproducing a (western) 'superculture' of film music, such a system of musical production was 'neither monolithic nor omnipotent' and consistently gave way to 'systematic cracks' that allowed 'for variation and even subversion' (Slobin, 2008b, p. 60); especially considering that he saw himself as an important agent of postcolonial nationalism.

I argue that Zubir Said and his compositions for film - despite the colonial and modernist limits within which they were created - had a crucially agential role in creating the sound palette of Malay national identity. Zubir Said's personal motivations appear in his own writings on Malay music, which are enthusiastic about the prospects of Malay national autonomy. The following is an excerpt from an article he wrote in 1958, shortly after independence in the Malay Peninsula:

During the age of merdeka music should as far as possible exert a positive influence on society. The music must be original, not imitations. Music should be the pride of the nation and convey the beliefs and values of the nation.

During the age of merdeka music should arise from a creativity that is free to explore new forms and ideas, but at the same time rational, while staying true to what is indigenous to the nation, even for modern compositions.

During the age of merdeka there should be an understanding that a nation's creativity should not be an exercise in imitation, rather it should be an effort to discover new forms of national music, grounded on the artistic expressions of the nation. (Zubir Said 2012a, p. 95) ${ }^{3}$

Zubir Said's manifesto on the importance of music in the construction of Malay nationalism reveals how he intended to create original music in his films that were also 'rational' in their references to a traditional Malay sound; more than that, he believed his compositions were 'staying true to what ... (was) indigenous to the nation, even for modern compositions'. Furthermore, the manifesto indicates the unquestionable importance that Zubir Said accorded his musical compositions in shaping the culture and character of the newly independent Malay nation.

Zubir Said himself was no stranger to the vibrant political exchanges of the Malay community in Singapore. During the postwar period, he had weekly informal group meetings with his peers of Minangkabau descent that included important Singaporean-Malay figures such as Singapore's first President, Yusof Ishak, the prominent journalist, Abdul Rahim Kajai and author Zainal Abidin Ahmad @ Za'aba (Zubir Said, 1984, Reel 12). It is highly likely that Malay-nationalist ideas about language and culture were exchanged in these meetings, with ideas from Zubir Said's more politicised peers having a direct impact on him and his consequent work. 
While drawing noticeably on this literary activist environment, Zubir Said contributed to the nation-making project of Singapore and Malaysia through a selection of patriotically-themed songs written for a concert in celebration of Malaysia's independence in 1957 (Barnard \& Van der Putten, 2008, pp. 148-150). Notably, Zubir Said's song, 'Majulah Singapura', that officially became a state anthem in 1959, would become the national anthem of Singapore upon the state's separation from the Federation of Malaysia in 1965 (Rohana Zubir, 2012, pp 3-19). However, his location is complicated by Zubir Said's fluid attachments to multiple spaces and identities: he was a citizen of the Dutch East Indies who migrated to Singapore to earn a living. While he subscribed to a strong patriotic attachment to 'Malay' (linguistic-cosmopolitan) nationalism, Zubir Said wrote the national anthem of a state that stood apart from neighbouring Malay nations as a 'non-Malay' state surrounded by the Malay world (see Rahim, 2009). Despite this apparent contradiction, it is undeniable that Zubir Said was influential in the process of Malay nation-making through music.

Amidst Zubir Said's musical articulations of self-determination, however, there remained a disjuncture between the new radical ideas of Malay film-makers and the rigid colonial structures of knowledge and power that largely remained in place in the industry. The Malay film studio industry in the 1950s had a social structure that loosely reflected the British colonial ideology of organising racial groups into specific labour roles: Chinese 'entrepreneurs' owned the studios and occupied technical positions (eg. camera operators, sound recordists, studio managers); Indians were the 'creatives' who directed, wrote scripts and occupied technical roles as well; and Malays were the 'performers' - the stars, musicians and composers ${ }^{4}$. Beyond the context of the entertainment industry, these socio-economic ethnic demarcations continue to feature in political contestations and negotiations of divergent 'nations-of-intent' in the postcolonial Malaysian state (Shamsul, 1996; Shamsul \& Sity, 2006). By the early 1960s, Malays began taking on greater roles of authority in the studios as directors and writers, replacing the previously 'imported' directors from India ${ }^{5}$. Zubir Said and Hussein Haniff worked for Cathay-Keris Studios, a Malay-language film studio operated by Ho Ah Loke, funded by the highly successful, Singaporean-based cinema company, the Cathay Organisation that was established in 1935 by Loke Wan Tho and his mother, Loke Cheng Kim. Thus, the creative economy exemplified here is one where the projection of ideas about postcolonial Malay nationalism on the silver screen were facilitated by the infrastructure and capital of Chinese-owned business. The rival Malay-film company, Shaw Brothers Malay Film Productions was, in parallel, funded by the Shaw Brothers who originated from Shanghai. While Peninsular Malaya had declared independence since 1957, Singapore was still a Straits Settlement under the administration of British empire. Film content produced in Singapore was routinely vetted by British censors. It is on this period of increasing Malay authorship, facilitated by Chinese capital in a colonial economy that I contextualise my musicalnarrative reading of Dang Anom. 


\section{Traditionalising Film Music}

Music-making operated as a practice of nation-making in the postcolonial era of Singapore's emerging Malay-language film industry. Music in Malay film was a means of making history through implying definitions of a 'tradition' demarcated by ethno-national boundaries. Concomitantly, Zubir Said's music articulated emergent nationhood through the genre of historically-themed films. ${ }^{6}$ This expressive space required Zubir Said to imagine and create a sonically 'Malay' aesthetic by drawing from his experience in local popular performing arts such as bangsawan musical theatre (Rohana Zubir, 2012, p. 44; Hamzah Hussin, 2012, pp. 67-69). Music in Malay film, thus, provides an insightful example of how national narratives are shaped through the authorial and creative agency of individuals despite the limits imposed by postcolonial conditions, assumptions and ideologies.

In this article, I analyse Zubir Said's film music "as a means of making history: not only as a form of social action directed at realising a future, but also as a medium for the retrospective definition of tradition" (Waterman, 1990, p. 369). I refer to this as a process of traditionalising music in Malay film, in which Zubir Said's film score is analysed as a historical text that uncovers the nationalistic sentiment of the Malay Peninsula in the 1950s and 1960s. The musical biography of Zubir Said and his creative process in composing for films reveals how Malay nationalists of the era conceived postcolonial sovereignty by evoking forms of cultural expression out of a pre-colonial past. This resonates with Smith's (1995) notion of 'ethnosymbolism' that considers the evocation of myths, values and symbols of an ethnic group's collective past in making a modern nation. Moreover, this cultural construction of nationhood, explained in Anderson's (2006 [1983]) study, is "an imagined political community - and imagined as both inherently limited and sovereign" (p.6). The conception of nation is defined by limiting boundaries such as geography, cultural communities or linguistic affinities while sovereignty relates to the nation imagined as being autonomous from 'divinely ordained' or 'hierarchical' dynastic spaces (p.7). What appeals greatly to music scholars is Anderson's example of how cultural groups are recognised 'not by their falsity/genuineness, but by the style in which they are imagined' (p.6; cited in Waterman, 1990, p. 376). Studies of 'expressive culture' and nationalism thus provide an integral point of departure for observing how nation-making is articulated as creative processes in cultural practices (Waterman, 1990, pp. 377378). Furthermore, in line with Chatterjee's (1993) views, I consider how music operates as an expression of 'national discourse' as 'human constructs seeking the status of the natural', positioned along 'two... axes' - one of 'territorial sovereignty' and the other, temporal, based on historical continuities and context ( $\mathrm{p}$. xi). I also draw inspiration from the substantial scholarly work that exists on modernist reformism in the 'classicisation' of Southeast Asian (Moro, 2004) and South Asian music (Subramanian, 1999, 2011; Bakhle, 2005; Weidman 2006; Schofield, 2010) in postcolonial contexts. While similarly in the Malay world, music as a cultural practice is often appropriated in nationalist projects of modernist reformism through the construction of musical traditions (Tan, 1993, 2005; Sarkissian, 2000, 2002). 
It is in this way that the musical aesthetics found in the film music of Zubir Said are referential to a discourse about emergent nationhood by actively creating an imaginary 'traditional' style that nonetheless assumes a 'natural' status of Malayness. The notion that this 'narrative of nationhood' was created or imagined musically is evident in Rohana Zubir's (2012) observations about her father when composing music for Malay films:

Having composed contemporary, modern music and now legendary music, ... (Zubir Said) found composing the legendary (historical-epic or mythical-themed film) music more challenging. For modern music he could listen to other recordings, but not so for legendary music, where he had to depend much on his own imagination. (p. 83)

For Zubir Said (1984), composing music for such films was most challenging because unlike films set in the modern era, he had no examples of Malay music to reference; thus, in his own words, he had 'to imagine it' or conjure a suitably Malay musical aesthetic based on his own creativity (Reel 13). In effect, Zubir Said invented Malay musical 'tradition' in his film music. Such creation of tradition however, was far from arbitrary as he did have his own personal preferences - as opposed to 'references' - as to what constituted 'Malay' music. Moreover, in the absence of a specific Malay-film-music tradition, there were nonetheless western art music conventions that Zubir Said drew upon for his original Malay film scores. He was not creating a folk music tradition but, rather, re-presenting the Malay tradition musically.

However, Zubir Said's compositions did inevitably draw from a template of Malay, regional and cosmopolitan musical styles and practices. He was originally trained in the practices of Malay bangsawan theatre; a genre already immensely diverse in cultural influences that was a hugely popular form of entertainment in the Malay Peninsula for a predominantly Malay-speaking audience (Tan, 1993). Rohana Zubir (2012) relates her father's illustrious musical career in pre-World War II Singapore that started in 1928 (p. 43). He started his professional musical career at the bangsawan Happy Valley Opera company playing violin, where he also learned to read western staff notation, (prior to this he was only adept in Sumatran numerical notation), western music theory, taught himself how to play the piano and eventually would go on to arrange music for and lead the company's orchestra (pp. 44-49). Following this, until the war, he became a talent scout and record producer of Malay-language music for the HMV record label based primarily in Jakarta (pp. 49-53). In addition to his bangsawan-musician background, Zubir Said also wrote music for films adapted from famous bangsawan plays including Jula Juli Bintang Tiga (The Tale of Three Magical Fairies), Yatim Mustapha (The Orphan Mustapha), and Gul Bakawali (Rohana Zubir 2012, p. 44; Hamzah Hussein, 2012, p. 69). However, a major difference between performing music for bangsawan and scoring music for Malay film was Zubir Said's authorial agency as a composer in creating a 'traditional' Malay musical aesthetic. In considering Zubir Said's vibrant cosmopolitan experience of music-making in Singapore during his bangsawan days, as well as his clearly defined yet complex Malay-nationalist stance on the arts, the 
next section analyses the traditionalised elements of his music in the film, Dang Anom.

\section{Scoring Tradition in Dang Anom (1962)}

The film, Dang Anom, portrayed on the surface as a historical Malay epic is in fact a modern melodrama. Its female protagonist, and namesake of the film, is the primary subject of a narrative that questions feudalistic or pre-colonial Malay values. Gledhill (1986) observes that melodrama films in the 1960s, despite their pejorative and commercial associations offered critical cinematic possibilities for "apparently ideologically complicit films to be read 'against the grain' for their covert critique of the represented status quo" (p.6). She explains how melodramatic forms allow for 'unthinkable' cultural and political ideas to "find a negotiable space in which certain contradictions and repressed desires are rehearsed" (p. 45).

The narrative structure and music of Dang Anom, while seemingly 'traditional' in style and context critique and re-imagine tradition in subversive and modern ways. Beyond the explicit critique of feudalism in the film's narrative there is also an underlying anti-colonial sentiment that resonates with the 'repressed desire' for a fully realised ethnonational autonomy. Thus, I aim in the following musical-textual analysis to unravel the convergences and disjunctures of film narrative, post-colonial power relationships, expressions of modernity, emergent nationhood and agency in Zubir Said's film music.

\section{Pre-colonial Setting, Post-colonial Narrative}

The narrative of Dang Anom is steeped in tragedy. It is framed as a Malay historical epic centered on the invasion of the Malay Temasek kingdom by the Javanese Majapahit empire. The film is, in fact, a modern melodrama that places idealistic agency in its female protagonist, Dang Anom (Fatimah Ahmad); critiquing the precolonial Malay feudalistic system as immoral and unjust. It is set in pre-colonial Temasek, the region known today as Singapore. Dang Anom, the main protagonist, is the daughter of Sang Rajuna Tapa (Ahmad Nesfu), a high-ranking minister in the court of the Malay Sultan of Temasek (M. Amin). She is tragically forced to become the concubine of the lustful Sultan when her lover, the warrior Malang (Noordin Ahmad), is sent to lead a war against the Javanese Majapahit kingdom. When Malang returns from his successful campaign he is distraught to learn of Anom's unfortunate situation. Eventually, the two lovers are 'framed' for treason by Malang's jealous enemy, Dato' Bijasura (Mahmud June) and are sentenced to death. Desperate to save his daughter, Anom's father reluctantly conspires with Majapahit spies to open the fortified gates to Temasek to facilitate an invasion of the Sultan's palace. The movie ends tragically with the death of Malang, Anom and her parents. Bijasura kills Anom's mother (Siti Tanjung Perak) who pleads to the Sultan for her daughter's life. At the end of the film, while the Sultan escapes Temasek with his consort, Anom is brutally raped and murdered at the hands of Bijasura and her 
father dies trying to save her. The film, then, is a Malay historical epic that paradoxically challenges the concept of feudal power. This is achieved through a narrative of tragedy and injustice experienced by the lead character that also reveals her ethical aspirations for self-determination and freedom.

Central to the film's narrative is Anom's position as a woman subjugated by patriarchal forms of control. Anom's body is contested between the Sultan and her lover, Malang, while the exchange of her ownership is mediated by her father. In this gendered power relationship the Sultan is symbolic of the antiquated practices of pre-colonial Malay society, while Malang is the archetype of a blindly loyal and powerless subject of feudal oppression. Intertextually and semantically, this character, whose name means 'unfortunate' in Malay represents an antithesis to the meaning of a more famous character from the famous Malay legend, Hang Tuah 'Tuah', is derived from bertuah, meaning 'fortunate' ${ }^{7}$. Anom's quest for selfdetermination and freedom, hence, positions her as a mediator of postcolonial modernist ideals.

This portrayal is in sharp contrast to the historical source of inspiration for the film, the Sejarah Melayu (Malay Annals). Brown's (2009 [1952]) translation of the Sejarah Melayu contains the story of an unnamed daughter of the Singaporean (Temasek) Sultan's treasurer, Sang Ranjuna Tapa, who was the 'mistress' to Sri Sultan Iskandar Shah (50). She was slanderously accused of 'misconduct' by other women in the Sultan's court and was 'publicly exposed' in the local market (pp. 5051). In Winstedt's (1938) version of the text, she was similarly accused of disloyalty to the Sultan and without investigation "impaled in the market square" (cited by Cheah 1993, p. 2). ${ }^{8}$ The main focus of this story in the text is the humiliation of Sang Ranjuna Tapa and his consequent treasonous role in assisting the Majapahit empire's conquest of Temasek. Unlike the Dang Anom film, the female concubine is not even named and merely a minor character in the narrative. The story of Sang Ranjuna Tapa's betrayal is linked to a generational curse due to the ruthless actions of the Sultan's father. In the moralistic vein of the Sejarah Melayu, the Sultan in repeating an unjust act is then punished with the loss of his kingdom to Majapahit. Cheah reads the women in this story as "capable of great guile, manipulation and ruthlessness which could produce deadly results" and further observes in the Sejarah Melayu instances of courtly women assassinating sultans and acting as major forces of resistance to oppressive monarchs (p. 2). Hussein Haniff's Dang Anom propels this pre-colonial proto-feminist role of women found in classical Malay narratives into a modern vision of women's resistance to feudalistic regimes. What role then, does music play in Malay feudal history? Andaya (2011) discusses the extension of Malay monarchical power in using loud sounds, particularly the nobat drum and wind ensemble. ${ }^{9}$ She argues that the use of sound-producing instruments in pre-modern Malay society sonically and symbolically reminded Malay villagers "of their subordination to the temporal power of the ruler" while reassuring them of their protection "by the supernatural powers such sounds evoked" (p. 32). Sounds in pre-modern Malay society "were part of an interactive acoustical space, conveying messages that helped to define a community's cultural parameters and affirm the place of the ruler at its emotional core" (ibid). Andaya's 
observation resonates with Zubir Said's score that attempted to portray a Malay tradition in Dang Anom's film music. The traditionalised music and dance in the film was used to symbolise feudalistic control over the film's protagonists. Considering Andaya's concept of sounded authority in the commercial and cosmopolitan context of Malay film music production highlights a paradoxical, musical critique of the inherent acoustic-kingship-kinship association. In the following sections, my analyses demonstrate how traditional-sounding music is not only used to denote and impose monarchical power but is also applied disjunctively, as a concealed critique of sounded authority which, by extension, questions the structural inequities of a postcolonial condition. Before engaging with a musicnarrative analysis of how tradition is challenged, I overview the musical arrangements, of melodic themes and instrumentation, in Zubir Said's score that establish an aesthetic of Malay musical tradition.

\section{Traditionalised Melodies}

The music of Zubir Said interacts with the melodramatic narrative of Dang Anom in unique ways by drawing on Malay melodies and styles combined with 'dark' or sombre-sounding, non-traditional textures to underscore the tragic narrative and modern subtext of the film. The orchestration sounds rich and full despite only using eight studio musicians - but is coded culturally and affectively through varying use of instrumentation. The instrumental music for the opening credits (title theme) starts with a distinct resonating gong strike followed by a gamelan-sounding descending melody played on a vibraphone (Figure 1). This acts as an indexical code for Javanese music, relating to the involvement of the Majapahit empire in the narrative. This 'Javanese' melody reappears in measure 9 and is hinted at with an ascending vibraphone melody at measure 23 towards the end of the piece (measure 23, Figure 2). Additionally, the use of a descending chromatic passage (measures 15 to 17, Figure 3) uncommon in Malay traditional and folk music provides melodic contrast to the 'sounded authority' of the 'Malay-sounding' melody (Andaya, 2011) that recurs frequently throughout the title theme, background music and songs in the film. All these musical devices converge with and complement the film's overarching allegory of self-determination in the face of unjust authoritarian rule.

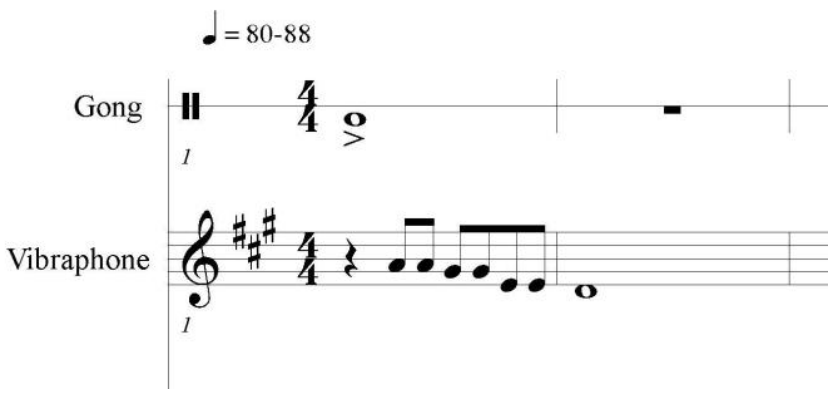

Figure 1. Gong hit and descending 'gamelan' melody (measures 1 to 2). 


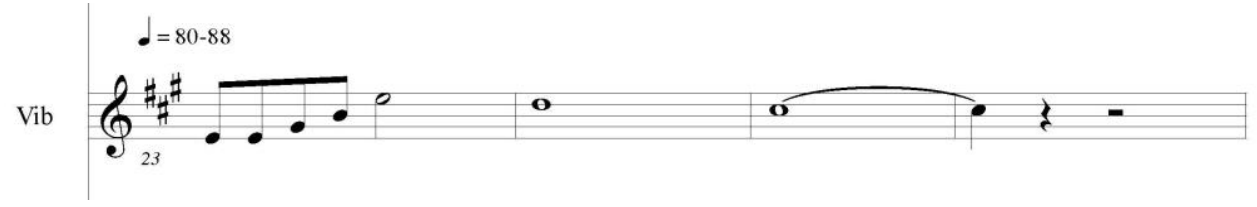

Figure 2. Ascending vibraphone (measure 23).

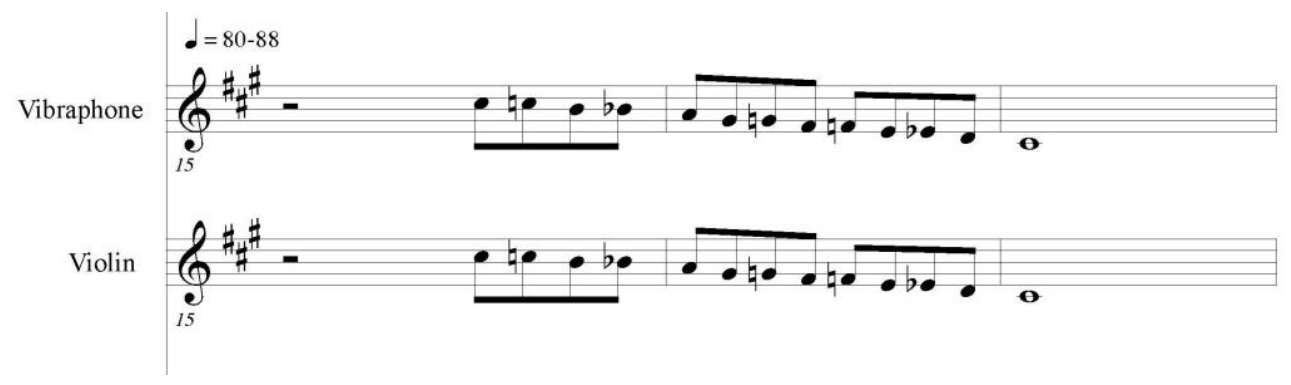

Figure 3. Chromatic descent (measures 15 to 17).

The instrumental music of the opening credits reiterates a 'freedom motif' as termed in Peters' analysis of Zubir Said's film music (2012, p. 87). I will call this melody and related variations the 'Dang Anom leitmotif' due to its frequent occurrence in the film and the centrality of the main character. Following the Javanese melody, the Dang Anom leitmotif (Figure 4) is announced by the violins (measures 2 to 7), rearticulated by a two-part saxophone section (measures 17 to 20, Figure 5), and finally, a solo electric guitar melody (measures 25 to 28, Figure 6). This motif is repeated in various orchestrations throughout the film, especially in the love duet between Dang Anom and Malang ('Berpadu Budi [United Gratitude]'), Dang Anom's lament and the final scene of the film where Dang Anom's father discovers his dead daughter (Peters, 2012, pp. 87-88). For example, the Dang Anom motif is articulated by flute and saxophone in this excerpt from the instrumental introduction to 'Berpadu Budi' in Figure 7 (measures 1 to 5).

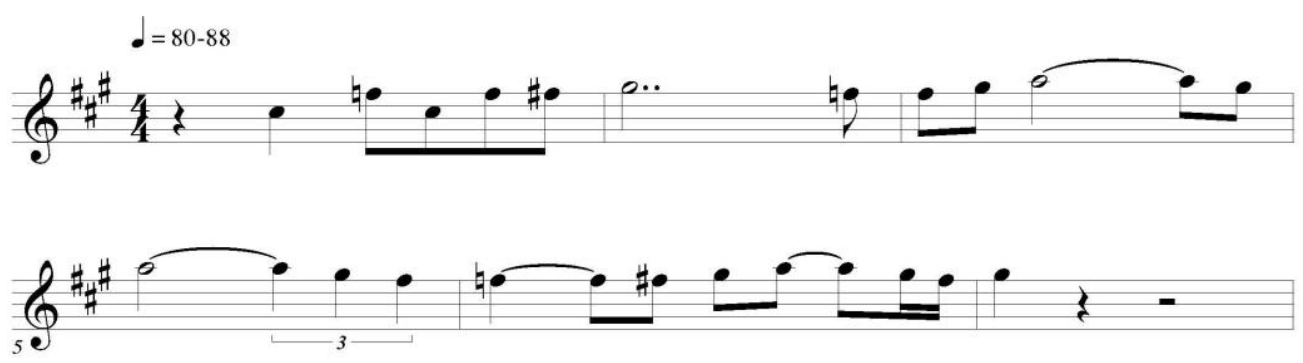

Figure 4. Violin motif (measures 1 to 5). 


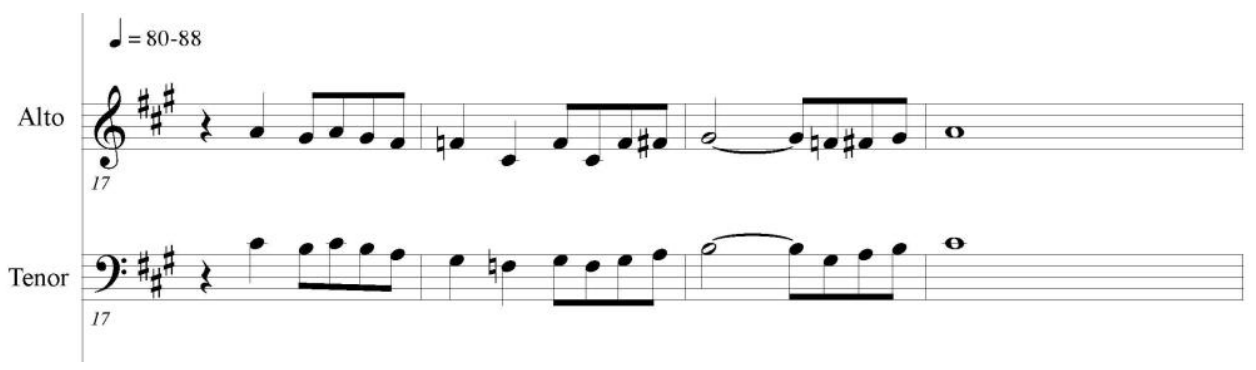

Figure 5. Saxophone motif (measures 17-20).

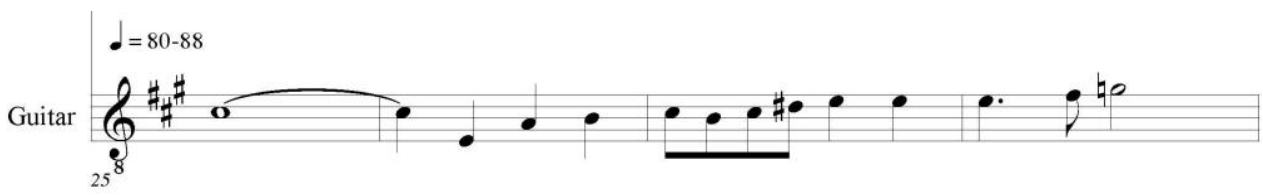

Figure 6. Guitar motif (measures 25-28).

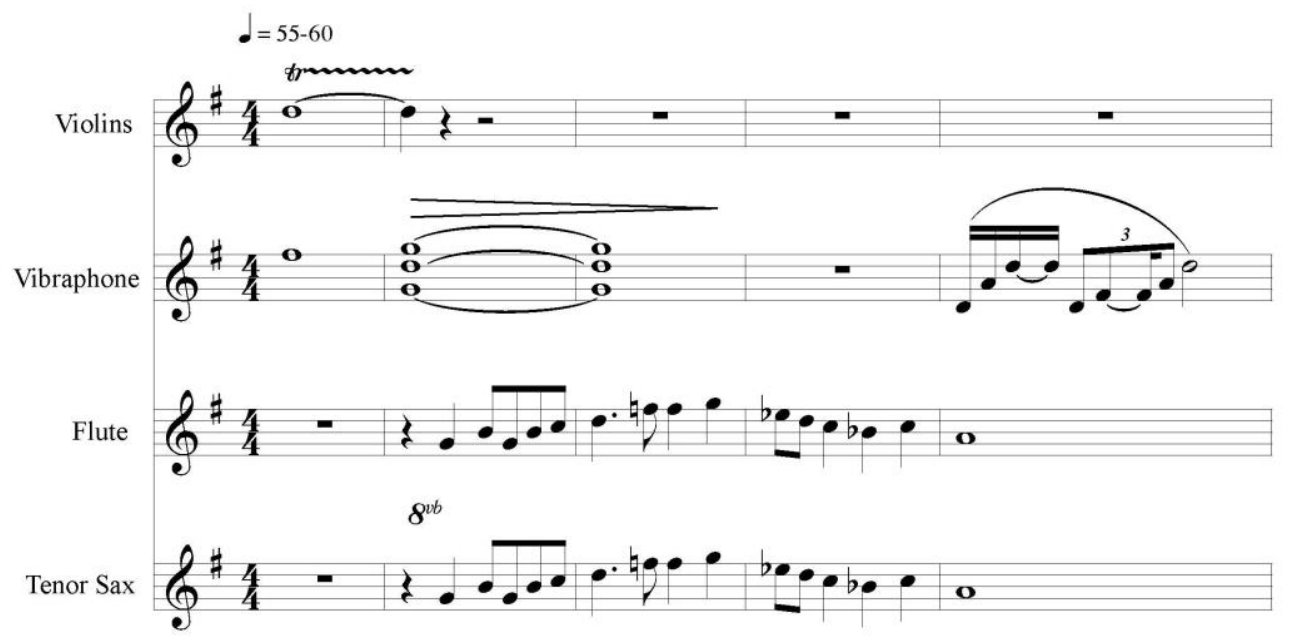

Figure 7. Instrumental introduction to the love duet, 'Berpadu Budi'.

The sequence of musical codes in the title theme sonically encapsulates the major narrative themes of the film. The musical themes are framed by the Javanese gamelan melody indicating the limited appearance but major role played by the Majapahit Empire in the story. The Dang Anom leitmotif played by the violin section refers to the cautiously optimistic idealism and love between the two main protagonists. In this, the violin signifies an 'authentic' Malay tradition as it has for centuries been integrated or adapted into Malay folk ensembles since the Portuguese colonial presence in the region. ${ }^{10}$ The tension between 'tradition' and 'modernity' 
or, in the context of the story, between feudal restrictions and individual aspirations, can be heard in the use of saxophones and electric guitar to play the Dang Anom leitmotif. Moreover, the saxophones are harmonised in sixths in an expression of western (or modern) tonality. While saxophones and other western instruments were common in the Orkes Melayu (Malay Music Ensembles) used in bangsawan theatre (Weintraub, 2010, pp. 38-41; Tan, 1993, pp. 76-78) it is therefore striking to hear such instrumentation in a 'traditional' Malay film epic.

Zubir Said's musical agency can be heard in relation to the aspiring agency of the film's female protagonist as an aesthetic disjuncture between modernity and tradition. When made a concubine, Dang Anom is resolute in her expression of unhappiness. Unlike the other concubines who eventually warm up to the lustful but charming Sultan, she expresses her displeasure openly to the point of her execution, rejecting the Sultan's plea to ask for his forgiveness in exchange for her life. The musical references in conjunction with the actions of Dang Anom are allegorical to the struggle for independence from colonial rule in the Malay Peninsula. The film music of Zubir Said, therefore, expresses a nation-making aesthetic inspired by modern cosmopolitan ideas of emergent national autonomy.

Further oppositions are observed in the composer's use of musical 'moods'. When composing for films, Zubir Said (1984) understood 'Malay' music to be rooted in vocal melody that was limited to two moods: 'happy singing... and sad singing' (Reel 13). This contrasting use of Malay musical 'moods' can be heard clearly in the two songs featuring Dang Anom in the film: initially, an aspirational love duet between Dang Anom and Malang; and later, a tragic lament sung by Dang Anom. Zubir Said's writing process involved extensive experimentation on the piano to create instrumental (background) music that he considered aesthetically suitable to Malay film (ibid). Moreover, he worked with a restricted budget of $\$ 3000^{11}$ per film and a meagre 'orchestra' of only eight musicians, which limited his goals to create lush and grand textures easily achieved with a larger orchestra (ibid). Because of this, he devised ingenious techniques to achieve his intended sounds by using more percussive instruments such as gongs and frame drums (ibid). In place of large or atmospheric orchestral textures the vibraphone is heard extensively in Dang Anom; providing a lush, dark, 'dreamy' and perhaps, ominous presence throughout the film's music. ${ }^{12}$ Thus, while restricting his music within self-imposed cultural boundaries, Zubir Said nonetheless composed music with a modernist aesthetic; using approaches that in fact challenged a rigid conception of tradition in music.

However, in line with a postcolonial conception of nationhood, a 'Malay' musical tradition, no matter how contested, had to be made visible even if it was not heard. A photograph of musicians recording at Cathay-Keris studio in the presence of Hussein Haniff (Figure 8) presents a traditionalised Southeast Asian spectacle: two angklung players, a gambus player, a flautist with wooden and metal flute, a kompang/rebana tar (cymballed-frame drum) player, a man standing by an Indonesian gong set $^{13}$ and Zubir Said holding a kompang and what appears to be three wooden flutes, a crash cymbal on a stand beside him, a harmonium and clarinet in front of him (Peters, 2012, p.76; Rohana Zubir, 2012, p. 29). It appears 
that this photo could have been taken as a 'behind-the-scenes' promotional shot in the recording studio, so additional instruments are placed for display such as more angklungs, a floor tom drum, a gendang and a rebana. What is noticeably absent from this photo are the modern instruments actually heard in Zubir Said's film scores such as the vibraphone, piano, guitar and saxophones. The most modern 'instrument' to be seen is the large microphone in front of Hussein Haniff. ${ }^{14}$ I can only speculate whether this was a 'traditional' instrument recording session or a conscious effort to promote the Cathay-Keris brand as being distinctly 'Malay'.

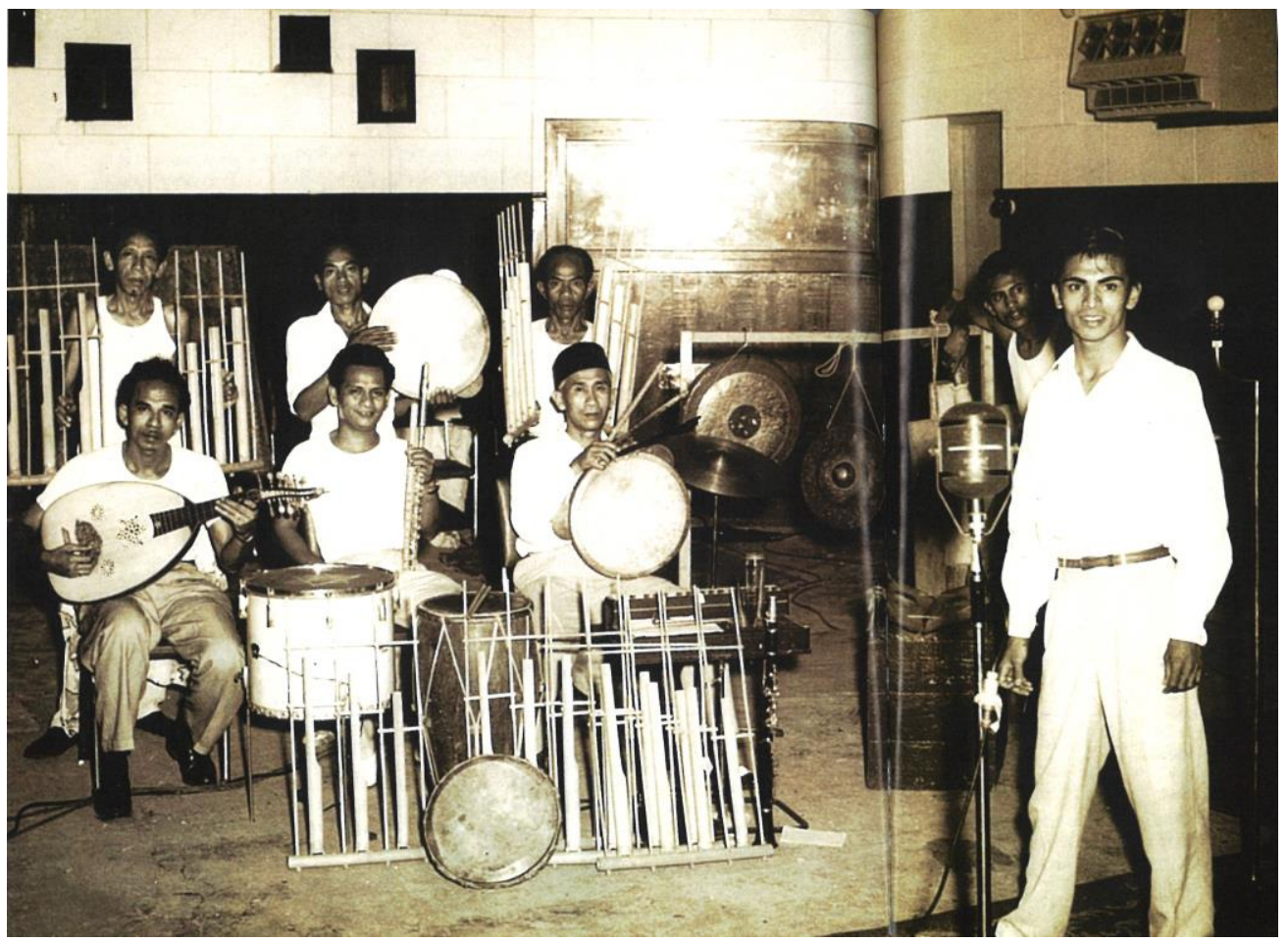

Figure 8. Zubir Said (seated, front row, first from right) and Hussein Haniff (standing, far right) (in Peters, 2012, p. 76; Rohana Zubir, 2012, p. 26).

In fact, Cathay-Keris distinguished its productions from their rival Shaw Brother's Malay Film Productions (MFP) by focusing on the genre of the Malay epic. Unlike MFP, Cathay-Keris was the only Malay film production company that allowed its composers to write original background music, whereas MFP's composers focused more on writing commercially viable songs. Thus, Cathay-Keris was known for its more 'traditional' aesthetic offerings in Malay film and music. The late Kassim Masdor (1999), a composer and musician who used to work for MFP as a continuity clerk suggests that the more aesthetically modern and commercially-inclined film songs from MFP had a greater mass appeal compared with Cathay-Keris' film songs that were 'more... traditional, which are harder to sing'15 (Reel 6). Kassim Masdor (1999) elaborates: 


\begin{abstract}
A lot of the film songs from Cathay-Keris were too excessively Malay. So, they were not accepted by society possibly because, sorry to say, they weren't that exciting but despite the Shaw Brothers films not having any, what people call very typical Malay songs... (Shaw Brothers film songs) have a commercial touch. (Reel 7, my emphasis)
\end{abstract}

This statement does not necessarily disparage the musical productions of CathayKeris but provides from the perspective of an experienced music composer from the era, an insight about the Malay film audience's musical taste in the 1950s and 1960s. ${ }^{16}$ The 'commercial touch' of prominent Shaw Brothers MFP song writers such as Osman Ahmad, Yusof B., P. Ramlee and Kassim Masdor constituted a cosmopolitan popular music aesthetic that included non-Malay styles of music such as jazz, samba and later, rock \& roll, albeit sung in the Malay language. The 'commercial' musical approach of the MFP Shaw Brothers' studio culminated in the final transition out of Malay folk and traditional music in the rock \& roll film $A G o$ Go '67 (1967, Dir. Omar Rojik) which featured Malay pop yeh yeh bands - rock guitar groups with singers a la the Beatles and Rolling Stones. Ironically, CathayKeris was the first studio to produce a rock \& roll-themed Malay film, Muda Mudi (Youths, Dir. M. Amin) starring Siput Sarawak and Roseyatimah, released in 1965. $A$ Go Go '67 was one of the last Malay films produced by the Studio in Singapore, marking the beginning of the end of a vibrant era of music in Malay films (Adil Johan, 2014).

\title{
Challenging Tradition
}

The traditionalising discourse that positions the music of Cathay-Keris films as 'excessively Malay' and 'very typical Malay' are ironic in retrospect, considering the modern approach and critique of tradition contained in those films. This modern approach is evident in the ample use of diegetic and non-diegetic disjunctures in these films that articulate a discourse of cultural and emotional conflict among the protagonists. The characters Malang and Anom are trapped within the boundaries of their culture and customs (adat), in which unquestioning loyalty to the Sultan is paramount. However, their cultural loyalties are significantly challenged when it devastatingly affects their personal relationship. Music is used to contrast the emotions of these characters at crucial points of conflict in the narrative. Furthermore, the use of traditional-sounding music disjunctive to the narrative amplifies the anti-authoritarian themes of the film's story. These music-narrative disjunctures can be musical scenes throughout the film. For this article, I analyse one scene in which Hussein Haniff's modern melodramatic narrative interacts with the multi-layered representations of tradition contained in Zubir Said's film music, articulating poetically and musically the contestations of power tied to postcolonial Malay nation-making.

In a scene set in the court of the Sultan, a group of female dancers are performing to celebrate Malang's triumphant return to Temasek ${ }^{17}$. The Sultan 
summons his concubines to be present for the festivities and Anom enters the room to a slow and melancholic melody that is diegetically heard as the introduction to a new dance. Suddenly, just as Malang notices her, the music is punctuated by a loud percussive accent that becomes a fast and lively percussive joget rhythm (Tan \& Matusky, 2004, p. 108). This sped-up tempo in the music is in stark contrast to Malang's unsettling realisation that his lover is now a concubine of the Sultan. Infuriated, he leaves the court in haste amidst the festive dance performance. The interplay of diegetic music in contrast with the repressed emotions of Malang and Anom operate to highlight the overarching anti-feudal theme in the film. The traditional dance music heard above everything else represents the subsuming limitations of a feudal culture in which individual desires and actions (except the Sultan's) need to be repressed. Additionally, the dance performances represent an embodied expression of loyalty to culture and tradition as well as a sexualised objectification of female subjects in service to the king's lustful desires. At this crucial point of the film, Malang leaves the court abruptly, unable to stomach the reality of his predicament.

This scene resonates with the notion of sounded authority mentioned earlier (Andaya, 2011). The portrayal of traditional Malay music and dance as a representation of the Sultan's authority in a disjunctive relationship to the narrative amplifies the critique of Malay feudal power. While the Sultan's authority and even his magnanimity is reflected in the festive occasion, it contrasts with the anger felt by Malang and the despair felt by Dang Anom when they see each other across the room. Upon Malang's abrupt exit from the festivities, he immediately goes to confront Anom's father. The exchange between Malang and Anom's father, Rajuna Tapa, clearly indicates the radical critique of tradition or Malay customs that fuels the film's narrative. Malang learns that Rajuna Tapa had no choice in giving up his daughter to the Sultan. This however, infuriates Malang even more. Upon Rajuna Tapa asking for him to be patient, Malang replies:

Sir, everything in this world has its limits. The same goes with patience... If the Sultan is free to appease his lustful desires then I too as a free human being should be free to express the words from my heart that are true.

Rajuna Tapa (RT): Your words are true but the citizens cannot be treasonous to the Sultan. Moreover, it is wrong on the side of our customs.

Malang (M): Ah! Customs! Are not customs a manifestation of desire to spread cruelty? Meanwhile, the Sultan is free to abduct people's children and wives to fulfil his lustful desires, but the citizens; the citizens are bound to ruthless customs. Where is the justice, Sir?

RT: Malang, do not give in to the feelings of your young blood. It will destroy your body.

M: Never, never. For the safety of Anom and the truth I am willing to sacrifice anything at all ${ }^{18}$ to demolish these ruthless customs. 
Here, Malang's overtly anti-feudal opinions critique Malay customs or tradition that allow for a monarch's unjust abuse of power. The exchange between Malang and Rajuna Tapa also reflect the tensions between the younger and older generations. Indeed, the Malay community in the 1960s was divided across a spectrum of beliefs: liberals, conservatives, monarchists, Islamists, socialists and Marxists (Harper, 2001; Kahn, 2006; Mohamad \& Aljunied, 2011; Aljunied, 2015). Hence, the exchange above not only articulates the tensions between Malay nationalists and the colonial order but also the antipathies within a diverse Malay community in a period of decolonisation and nascent independence. Some sought a more conservative approach to independence that upheld the integrity of the Malay monarchy, while others wanted a more radical change: a dissolution of the monarchy altogether.

The social critique derived from the film's narrative and dialogue is even more complex, however, when considering the film's music. What can be heard in the film's music then, is a representation of tradition that contrasts with the radical, 'anti-tradition' message of the film. Traditionalising music is used to signify the 'sounded authority' of the Malay feudal order (Andaya, 2011) but a closer, intertextual reading of such music reveals a more nuanced relationship. The Dang Anom leitmotif articulates two opposing notions. On one hand, the leitmotif is a rigid structural imposition of formal western compositional practices; it assumes the baggage of colonial modes of structuring, simplifying and other-ing the culture of the colonised. On the other hand, the musical convergence of western conventions with local music is congruent with the postcolonial process of nation-making; Zubir Said and Hussein Haniff were actively creating their own nuanced discourse about Malay nationhood in Dang Anom. It was a discourse about the paradoxes and contestations of an emerging Malay nation that was potentially bound by conservative notions of tradition and a colonial mentality of dependence. The tragic narrative of Dang Anom, however, loudly implores its audience to challenge corrupt leaders who derive their power from tradition, customs or archaic belief systems. In this allegory for ethical nation-making, the musical tradition scored by Zubir Said represented his own desire for a modern Malay nation that could free itself from colonial dependency; adapting the local musical practices of the past to the aspirations of the present.

\section{Conclusion}

Listening to Zubir Said's film music uncovers how a postcolonial nation is scored through the evocation of tradition. The constitution of 'national traditions' is strongly predicated upon the existence of a supposedly unchanging repository of culture. I argue that the film music composed by Zubir Said demonstrates the reverse in that he was instrumental in the process of creating an aesthetic of Malay musical tradition for the nascent postcolonial nation. Malay musical practices prior to colonial rule were already intensely pluralistic and cosmopolitan. Therefore, the process of creating a musical tradition for an emergent Malay nation was a selective 
process facilitated by creative individuals in positions of nation-making. Zubir Said was a composer that was given the opportunity to compose a 'modern' musical 'tradition' for an emerging Malay nation, using ambiguous cultural boundaries of Malayness that were and remain contestatory and processual (Waterman, 1990; Barnard, 2004; Shamsul, 2004). Zubir Said had to creatively score a Malay musical tradition for the silver screen, drawing on, at his own discretion, selected musical genres, instrumentation and folk melodies to portray a sense of musical authenticity rooted in an 'imagined' organic past. While Malay films drew on Malay feudal history as a source of its vernacular cultural past, the traditional-sounding music and melodramatic narratives of such films contested archaic notions of tradition to articulate a subversive message of ethical modernity, freedom and selfdetermination. The disjunctive narrative juxtaposition of Malay folk music and dances like the joget, to harmonising a Malay melody in sixths on saxophones was evident in Zubir Said's film score. These approaches to film music were expressed in tandem with the radical ideology of Malay nationalists active in the Malay literary, print, film and music community; subversively sounding a postcolonial critique of unequal power relations between despotic rulers and innocent subjects, British rule and Malay activism, colonial oppression and self-determination. Through their narrative works, Malay literary activists, film-makers and composers championed new postcolonial ideals by challenging antiquated notions of Malay feudalism. Paradoxically, as a composer of traditionalised Malay music, Zubir Said also occupies a position of authority in the retrospective and prospective definition of 'Malayness' (Shamsul, 2004). Thus, his music then forms an aesthetic template for a Malay 'nation-of-intent' that is mobilised in the ethno-national hegemony of Malaysia's (not Singapore's) National Cultural Policy (Nagata, 2011; Shamsul \& Sity, 2006). As one of the first film composers for the postwar Malay film industry, Zubir Said was instrumental in initiating a musical aesthetic discourse of Malay nation-making that resonated throughout Malay films of the early 1960s.

\section{Acknowledgements}

The author would like to thank the staff of the Malay Heritage Centre Singapore, Singapore National Museum, National Archives of Singapore and organisers of the Majulah! Film Music of Zubir Said Festival (2012) who were invaluable in providing insights and research materials for this study. Research conducted for this study was made possible by the King's College London Continuation Scholarship (2012-2014) and a period of fieldwork from July to August 2013 hosted by the National University of Singapore, funded by the King's College London Partnership Grant. An earlier version of this article was presented at the The $8^{\text {th }}$ Asian Graduate Forum on Southeast Asian Studies, Singapore (22-26 July 2013), organised by the Asia Research Institute (ARI), National University of Singapore. 


\section{Endnotes}

${ }^{1}$ The film Buloh Perindu (1953), Dir, B.S. Rajhans was also the first film produced by the newly set up Cathay-Keris Film Productions (Hamzah Hussin 2012, 63).

${ }^{2}$ Slobin (2008a) terms this aesthetic of film music the 'Steiner superculture' - a reference to the classically trained composer, Max Steiner, whose methods to film scoring in the 1930s have become the 'norm' for all film music since.

${ }^{3}$ It is worth mentioning the striking similarities of Zubir Said's views with English composer and staunch music-nationalist, Ralph Vaughan Williams' expressed at length in his book, National Music and Other Essays (1987). Williams' essay entitled 'National Music' was published in 1934, so it is highly likely that Zubir Said could have been inspired by Williams' ideas, although this cannot be confirmed in any existing sources on Zubir Said.

${ }^{4}$ British authorities during their colonisation of the Malay Peninsula categorised the economic activities of colonised people by race: the Chinese were small business-owners and traders, the Indians were estate-workers and labourers (although some South Asian castes occupied professional positions and operated businesses), the Malays were mostly farmers and fishermen (see Alatas 1977 and Lim 1984).

${ }^{5}$ While these directors were 'imported' from India and were Indian nationals, it is worthwhile to note that South Asian communities and culture existed in the Malay world centuries prior to European colonialism. The South Indian director of Malay films, L. Krishnan, would stay on and eventually become a Malaysian citizen and successful producer of Malay films past the demise of Singaporean Malay studio film industry (see Prem K. Pasha 2003).

6 'Historical' Malay films were also termed bangsawan films in reference to the repertoire of narrative themes derived from bangsawan (translated, 'nobility') plays set in the feudalistic pre-colonial past of the Malay World. Such stories were derived of classic Malay texts such as Sejarah Melayu (Malay Annals), Hikayat Hang Tuah (The Romance of Hang Tuah), Hikayat Merong Mahawangsa (The Romance of Merong Mahawangsa), etc. Interestingly, Malay film magazines such as Majalah Film (1960-1965) refer to such historically themed films as bangsawan films in contrast to masyarakat (social) films set in modern, urban contexts.

${ }^{7}$ For a deeper analysis of Malay identity and masculinities represented in Hang Tuah narratives across literature and film see Khoo (2006).

${ }^{8}$ Again, further parallels can be drawn to South Asian musical and filmic culture. The tragic history of subjugation of the North Indian female courtesan is elaborated Schofield's article that ties in the history of the courtesan with their typecast tragic narrative trajectory in Hindi film representations (2012, p. 165, citing Booth [2007, p.7]). Also see Booth's article on female courtesan protagonists in Hindi films (2007).

${ }^{9}$ Also see, Malay nobat: A history of encounters, accommodation and development by Raja Iskandar Raja Halid, a PhD. thesis submitted to King's College London in 2015.

${ }^{10}$ The combined use of the rebana and violin is one example of pre-modern cosmopolitan Malay instrumentation; Kartomi has suggested its connection to Moorish culture imported by Portuguese colonists to the Malay Archipelago (1988 cited in Tan, 1993, p, 77, supra note 6; also see Tan, 2005)

${ }^{11}$ The currency stated is in Malaysian Ringgit $(\$)$ that was at the time valued at $£ 0.14$ for $\$ 1.00$. Most Malay films would have an overall budget of $\$ 30,000$. Hence, the budget for music was only one-tenth of a film's entire budget. 
12 The vibraphone is not an instrument common to Malay folk music but it was immensely popular in Malay films from the 1950s to 1960s. Zubir Said's use of the vibraphone can be heard in most of his film scores, notably for films set in mythical or historical settings such as Bawang Puteh Bawang Merah (Garlic and Onions, 1959, Dir. Salleh Ghani) and Jula Juli Bintang Tujoh (The Magical Tale of the Seven Fairies, 1962, Dir. B.N. Rao).

${ }^{13}$ The man is Wahid Satay, a popular actor at Cathay-Keris known for comedic acting and singing abilities.

${ }^{14}$ For more on the role of the microphone in shaping the aesthetics of modern recorded music see Théberge (2001).

15 ،... kita punya (lagu) more to modern. Cathay-Keris punya more to traditional yang payah dinyanyikan'

${ }^{16}$ It would be ideal to illuminate this view with responses from lay-persons who had viewed films from this era. However, this is currently beyond the scope of this study and warrants its own study that considers an audience-centred historical ethnography on the reception of Malay film music.

${ }^{17}$ The dance here features Lela Sani who is mentioned in the title credits.

${ }^{18}$ This is an apt intertextual reference by Hussein Haniff to P. Ramlee's song "Berkorban Apa Saja (To Sacrifice Anything At All" in the film, Hang Tuah (1956, Dir. Phani Majumdar).

\section{References}

Adil Johan (2014). Disquieting degeneracy: Policing Malaysian and Singaporean popular music culture from the mid-1960s to early-1970s. In B. Barendregt (Ed.), Sonic modernities in the Malay world: A history of popular music, social distinction and novel lifestyles (1930s - 2000s) (pp. 136-161). Leiden: Brill.

Alatas, S. H. (1977). The myth of the lazy native: Oxon: Frank Cass and Company Limited.

Aljunied, S. M. K. (2015). Radicals: Resistance and protest in colonial Malaya. DeKalb, Illinois: University of Illinois Press.

Andaya, B. W. (2011). Distant drums and thunderous cannon: Sounding authority in traditional Malay society. International Journal of Asia Pacific studies, 7(2), 19-35.

Anderson, B. (2006). Imagined communities: Reflections on the origins and spread of nationalism (Revised). London: Verso (Orig. pub. 1983).

Anonymous. (2009). Malay annals. (C. C. Brown, Trans.) (28th ed.). Selangor: The Malaysian Branch for the Royal Asiatic Society (Orig. pub. 1952).

Barnard, T. P. (Ed.). (2004). Contesting Malayness: Malay identity across boundaries. Singapore: Singapore University Press.

Barnard, T. P., \& Van der Putten, J. (2008). Malay cosmopolitan activism in post-war Singapore. In M. D. Barr \& C. A. Trocki (Eds.), Paths not taken: Political pluralism in post-war Singapore (pp. 132-153). Singapore: NUS Press.

Bakhle, J. (2005). Two men and music: Nationalism in the making of an Indian classical tradition. Oxford: Oxford University Press.

Booth, G. D. (2007). Making a woman from a Tawaif: Courtesans as heroes in Hindi cinema. New Zealand Journal of Asian Studies, (9), 1-26. 
Born, G., \& Hesmondhalgh, D. (2000). Western music and its others: Difference, representation and appropriation and music. Berkeley \& Los Angeles, California: University of California Press.

Chatterjee, P. (1993). Nationalist thought and the colonial world: A derivative discourse. Minneapolis: University of Minnesota Press.

Gledhill, C. (1986). "Stella Dallas" and feminist theory. Cinema Journal, 25(4), 44-48.

Hamzah Hussin. (2012). Zubir Said: Man of music. In Norlia Embong \& Ibrahim Tahir (Trans.), MAJULAH! The film music of Zubir Said (pp. 62-72). Singapore: National Museum of Singapore.

Harper, T. (2001). The end of empire and the making of Malaya (2nd ed.). Cambridge: Cambridge University Press (Orig. pub. 1999).

Kahn, J. S. (2006). Other Malays: Nationalism and cosmopolitanism in the ,modern Malay world. Singapore: Singapore University Press.

Kassim Masdor. (1999, May 13). Reel 1-8 [Cassette].Khoo, G. C. (2006). Reclaiming adat: Contemporary Malaysian film and literature. Vancouver \& Singapore: UBC Press $\&$ NUS Press.

Lim, T. G. (1984). British colonial administration and the "ethnic division of labour in Malaya." Kajian Malaysia, 2(2), 28-66.

Matusky, P., \& Tan, S. B. (2004). The music of Malaysia: The classical, folk and syncretic traditions. Aldershot: Ashgate.

Mohamad, M., \& Aljunied, S. M. K. (Eds.). (2011). Melayu: Politics, poetics and paradoxes of Malayness. Singapore: NUS Press.

Moro, P. (2004). Constructions of nation and the classicisation of music: Comparative perspectives from Southeast and South Asia. Journal of Southeast Asian Studies, $35(2), 187-211$.

Nagata, J. (2011). Boundaries of Malayness: "We have made Malaysia: Now it is time to (re)make the Malays but who interprets the history?" In Melayu: Politics, Poetics and Paradoxes of Malayness. Singapore: NUS Press.

Peters, J. (2012). Zubir Said and his music for film. In MAJULAH! The film music of Zubir Said (pp. 74-90). Singapore: National Museum of Singapore.

Prem K. Pasha. (2003). The Krishnan odyssey: A pictorial biography of Dato' L. Krishnan. Kuala Lumpur: NASAREE.

Rahim, L. Z. (2009). Singapore in the Malay World: Building and breaching bridges. Oxon: Routledge.

Raja Iskandar Raja Khalid. (2015). Malay nobat: A history of encounters, accommodation and development. King's College London, London.

Rohana Zubir. (2012). Zubir Said, the composer of Majulah Singapura. Singapore: ISEAS Publishing.

Sarkissian, M. (2000). D'Albuquerque's children: Performing tradition in Malaysia's Portuguese settlement. London: University of Chicago Press.

Sarkissian, M. (2002). Playing Portuguese: Constructing identity in Malaysia's Portuguese community. Diaspora: A Journal of Transnational Studies, 11(2), 215-232.

Schofield, K. B. (2010). Reviving the Golden Age again: "Classicization”, Hindustani music, and the Mughals. Ethnomusicology, 54(3), 484-517.

Shamsul A.B. (1996). Nations-of-intent in Malaysia. In S. Tonesson \& H. Antlov (Eds.), Asian Forms of the Nation (pp. 323-347). London and New York: Routledge Curzon. 
Shamsul Amri Baharuddin. (2004). A history of an identity, an identity of a history: The idea and practice of "Malayness" in Malaysia. In T. P. Barnard (Ed.), Contesting Malayness: Malay Identity across boundaries. (pp.135 - 148). Singapore: Singapore University Press.

Shamsul Amri Baharuddin \& Sity Daud. (2006). Nation, ethnicity, and contending discourse in the Malaysian state. In R. Boyd \& T.W. Ngo (Eds.) State making in Asia. (pp.131-140). London: Routledge

Slobin, M. (2008a). The Steiner superculture. In M. Slobin (Ed.), Global soundtracks: Worlds of film music (pp. 3-35). Middletown, Connecticut: Wesleyan University Press.

Slobin, M. (2008b). The Superculture beyond Steiner. In M. Slobin (Ed.), Global soundtracks: Worlds of film music (pp. 36-62). Middletown, Connecticut: Wesleyan University Press.

Smith, A.D. (1995). The Ethnic Origins of Nations. Oxford: Blackwell Publishers Ltd.

Subramanian, L. (1999). The reinvention of tradition: Nationalism, carnatic music and the Madras Music Academy, 1900-1947. Indian Economic Social History Review, 36(2), 131-163.

Subramanian, L. (2011). From the Tanjore court to the Madras Music Academy: A social history of music in South India (2nd ed.). Oxford: Oxford University Press.

Tan, S. B. (1993). Bangsawan: A social and stylistic history of popular Malay opera. Singapore: Oxford University Press.

Théberge, P. (2001). "Plugged in": Technology and popular music. In S. Frith, W. Straw, \& J. Street (Eds.), The Cambridge companion to pop and rock (pp. 1-25). Cambridge: Cambridge University Press.

Waterman, C. A. (1990). "Our tradition is a very modern tradition": Popular music and the construction of a pan-Yoruba identity. Ethnomusicology, 34(3), 367-379.

Weidman, A. J. (2006). Singing the classical, voicing the modern: The postcolonial politics of music in South India. London: Duke University Press.

Weintraub, A. N. (2010). Dangdut stories: A social and musical history of Indonesia's most popular music. New York, NY: Oxford University Press.

Williams, R. V. (1987). National music and other essays. Oxford: Oxford University Press.

Winstedt, R. O. (1938). Sejarah Melayu. Journal of the Malayan Branch of the Royal Asiatic Society, XVI (III), 1-226.

Zubir Said. (1956, 1957). Bahasa Melayu dalam nyanyian (The Malay language in song). Presented at the Kongress Bahasa dan Persuratan Melayu III (The Third Congress on Malay Language and Literature), Singapore and Johor Bahru.

Zubir Said. (1967). Menuju tahun 1967, Filem Malaysia, 1, 20-21, 45.

Zubir Said. (1984, September 7). Reel 11-15.

Zubir Said. (2012a). Music in the age of merdeka. In Norlia Embong \& Ibrahim Tahir (Trans.), MAJULAH! The film music of Zubir Said (pp. 94-97). Singapore: National Museum of Singapore.

Zubir Said. (2012b). The development of Malay music. In Norlia Embong \& S. Ibrahim Tahir (Trans.), MAJULAH! The film music of Zubir Said (pp. 98-103). Singapore: National Museum of Singapore. 


\section{Biography}

Adil Johan is a research fellow at the Institute of Ethnic Studies (KITA), Universiti Kebangsaan Malaysia (UKM). His doctoral thesis in music research and ethnomusicology was awarded by King's College London in 2015. He currently has a forthcoming book that will be published with National University of Singapore Press, which examines postcolonial nation-making, cultural intimacy and the cosmopolitan music of Malay-language films in 1950s to 1960s Singapore and Malaysia. His current research interests include the cultural politics and cultural consumption of popular music, social media and digital technology in film and music, the politics of ethnicity and histories of postcolonial nation-making. As a musician, he currently plays the saxophone in two projects; the folk rock collective, Azmyl Yunor \& Orkes Padu, and Malaysian-rock-fusion band, Nadir. 